\title{
INTRODUCING A CLIENT-CENTRED FOCUS INTO THE LAW SCHOOL CURRICULUM
}

\author{
ROBIN HANDLEY* AND DAMIEN CONSIDINE**
}

[This paper examines recent research showing widespread dissatisfaction with the legal profession, especially as a result of failures in lawyer/client communications. We ask whether part, at least, of the blame lies with law schools, who largely neglect the client in the law degree curriculum. The question then posed is, what is the role of our law schools and to what extent should clients be a part of their perspective, particularly at a time when the nature of legal practice is undergoing profound change. One indication of this is the emphasis or lack of emphasis given to teaching skills in the law degree curriculum, especially those skills which give context to the law and affect the consumer of legal services, the client. We consider the relationship between the law degree and practical legal training courses, what skills are currently taught by law schools, and ask what skills might be included in the law degree curriculum and with what effect. We conclude that a client-centred approach to legal education - one which includes the client in the law school curriculum - could make a significant contribution to redressing failures in lawyer/client communication and also make the law degree a more focused and interesting course of study.]

\section{CLIENT DISSATISFACTION IN NSW}

There have been a number of recent research reports published drawing attention to levels of client dissatisfaction with the legal profession in NSW, ${ }^{1}$ together with other data showing a high level of client complaints and notifications of potential negligence claims.

A Report, entitled Plaintiffs and the Process of Litigation, in a series of studies conducted by the Civil Justice Research Centre on the level of satisfaction of plaintiffs in the 1992 Supreme Court Special Sittings, was published in December 1994. ${ }^{2}$ This revealed that $51 \%$ of plaintiffs were dissatisfied with the level of information provided to them by their lawyers, $67 \%$ were dissatisfied with the level of control they had over their case, and $80 \%$ would have liked to participate more in the settlement negotiations. ${ }^{3}$ The conclusions which can be drawn from the report are that the following matters are central to the level of client satisfaction with the outcome of their case:

- lawyers should provide adequate information to clients about the legal process and keep them properly informed about the progress of their case;

- clients should perceive they are in control of their case; and

- lawyers should encourage client participation in the conduct of their case, especially in control and decision-making.

The study reveals that these matters are currently neglected to a significant degree by many lawyers, with the result that, commonly, the expectations of plaintiffs are not matched by reality. This leads to dissatisfaction with the outcome of their case, with the legal process and with the legal profession.

A 1994 Working Paper published by the Centre for Language in Social Life, The Language of LawyerClient Conferencing ${ }^{4}$ also endorses a "participatory model of lawyer-client relationships, in which clients are encouraged to ask questions and to make decisions on matters relevant to their problem or case". ${ }^{5}$ The Working Paper recommends a Professional Development Program which, among other things, sensitises lawyers "to the collaborative, goal-orientated nature of the lawyer-client conference". ${ }^{6}$

In August 1994, a Report, Managing Client Expectations and Professional Risk ${ }^{7}$ was published, based on a risk management project initiated mid-1992 by Lawcover, the NSW professional indemnity insurer. 
The Report reveals how professional negligence claims arise when the client's expectations — at the outset or subsequently — are not met by what the solicitor delivers ... they often arise when the solicitor has failed to understand and respond to the client's expectations, regardless of whether these expectations are reasonable or not. ${ }^{8}$

The Report revealed that over a 5 year period an average of one in every two solicitors will be involved in a formal claim lodged with the professional indemnity insurer. ${ }^{9}$ The Report points out that this is only the tip of the iceberg because "many similar situations — even serious ones — never reach the stage of becoming a formal claim, usually because the parties involved resolve their differences by discussion or because the client doesn't pursue the matter". ${ }^{10}$

The Report outlines how four-fifths of claims fall into four dominant groups of causal symptoms:

- Handling the Client Interface. This is the most significant group accounting for about one third of all claims by both number and value. ${ }^{11}$ Claims in this group arise from failure to establish and maintain an effective working relationship with the client.

- Handling File. This group accounts for about one fifth of the number of claims and about one sixth of the cost. ${ }^{12}$ Common examples are missing time limits (eg in litigation) or failure to properly maintain the file (eg failure to record and file notes of interview or of telephone conversations with the client).

- Knowing/Applying Law. This group accounts for about one seventh of the cost of claims, and most commonly involves drafting errors. ${ }^{13}$

- Handling Details. About one tenth of the cost of claims arises from failures to check details. ${ }^{14}$

Thus, the most significant group of claims concern solicitor/ client communications, and the second most significant group is directly related to solicitor/client communications.

Chapter 4 of the Report states that the "most significant cause underlying professional negligence claims is the basic professional attitudes of solicitors involved in the claims to the process of providing the legal service”, referred to as engagement management. ${ }^{15}$ There are five essential ingredients:

- Setting up the engagement. The Report suggests that solicitors often fail to think through what is involved in delivering a service to the client, and fail to allocate sufficient time to it, including developing a shared understanding between the solicitor and the client.

- Managing client expectations. Many solicitors “fail to recognise and manage the 'expectation gap' — a difference between what the' client expects and what is likely to be achieved”. ${ }^{16}$ Often the problem stems from the initial interview when the solicitor fails to explore the client's expectations.

- Varying the terms of the agreement. Matters will develop and change with time. Typically, solicitors fail to discuss the change and its implications with the client. ${ }^{17}$ Writing to the client. Too many solicitors avoid writing to the client, initially to confirm the client's instructions, and then as the matter proceeds. ${ }^{18}$

- Ending the engagement. A solicitor must spell out clearly when the engagement with the client is at an end. ${ }^{19}$ Once again, much of this is a matter of effective communication between solicitor and client. Chapter 6 of the Report specifically addresses problems caused by lack of interpersonal skills in dealing with the client and, in particular, failure to listen to the client, ask appropriate questions and explain relevant aspects of the matter and its progress. ${ }^{20}$ Commonly the solicitor has failed to devote enough time or attention to the matter. The Report warns this is a particular problem for experienced solicitors who "tend to fall into the trap of making up their own minds on the legal issues and how to handle them before all the facts and issues are 'on the table'”. ${ }^{21}$

There is other recent statistical evidence indicating that in New South Wales the most significant cause of complaints against lawyers and of claims for professional negligence is a failure of communication between lawyer and client. Statistics published in the NSW Law Society Journal ${ }^{22}$ that more than 2000 complaints against lawyers were made to the Professional Standards Department of the NSW Law Society in the 12 months to 31 May 1994: "the number of practitioners divided by the complaints per year suggest that there will be an average of one complaint each ten years per practitioner”. ${ }^{23}$ Figures from LawCover, the NSW professional indemnity insurer, reveal 1352 notifications of claims and circumstances that could give rise to claims ${ }^{24}$ were received in respect of NSW, ACT, Tasmania and Western Australia ${ }^{25}$ for the 12 months to 30 June $1995 .^{26}$ The Legal Services Commissioner for NSW, Steve Mark, in his first Annual Report for the 12 months ending 30 June 1995, stated that $60-70 \%$ of the complaints received at his office "are based on communication problems between the legal practitioner and the consumer". ${ }^{27}$ 
Following the 1994 publication of Managing Client Expectations and Professional Risk ${ }^{28}$ on professional negligence exposure in the legal profession, LawCover has been so concerned about the problem that it has initiated a Risk Management Education Program, launched on 24 August 1995. ${ }^{29}$ The principal objectives of this program are to raise the awareness, understanding and personal skills of all solicitors in the following areas:

- engagement management

- managing the legal issues

- listening, asking and explaining

- quality assurance and risk management. ${ }^{30}$

The program comprises the above four modules, each lasting about four hours, which practitioners will be encouraged to attend by LawCover providing a full rebate of program costs by deduction from premium contributions over a period of two years after successful completion of the program. Although the focus of the program is understandably that of risk management, it should be noted that the first three of the four modules largely involve issues of solicitor/client communication.

\section{ARE THE LAW SCHOOLS TO BLAME?}

If lawyer/client communication problems are a common feature in the legal profession, why is this? To an outsider, it might seem obvious that good communications with the client are fundamental to the provision of a professional service. Perhaps at least some of the blame lies with the nature of the legal education provided by our law schools. Do law schools give students a false impression of legal practice, suggesting that legal practice is primarily about resolving complex issues of law? Because, of course, this is not the focus of most legal practice, which is concerned primarily with handling a variety of transactions, helping resolve disputes, providing advice etc, most of which are more concerned with issues of fact rather than issues of law.

\section{The Current Focus - Client Free}

At law school, the focus of many subjects studied is the development of the common law, relevant legislation and perhaps law reform. Existing law is interpreted either by direct reference to its primary source, in particular the judgments of higher and appellate courts, or according to the analysis of secondary sources such as the reports of law reform commissions, other commissions/committees of inquiry or textbook writers who themselves draw on that same primary source. So where do clients fit in? Often they do not?' particularly if the teaching of a subject relies on a form of Socratic case method which encourages students to develop analytical skills to ascertain the principles of law from decided cases. ${ }^{32}$

Such a method, while deriving principles from specific cases, nevertheless focuses primarily on legal principle and any inconsistencies and contradictions in the court's formulation. The outcome of the case and its effect on the individual client is often not considered. For example, the extracts of cases included in casebooks on substantive law commonly do not include any indication of the end of the story To be fair, this may be because there is no indication of how the story ends in the law report. But students are left wondering what happened. The human interest angle - how the law operates in practice - is too often neglected, yet this is what makes the law interesting for many students.

\section{The Problem Method of Learning}

Of course, many law schools have long used the problem method of learning, ${ }^{33}$ analysing a briefly stated hypothetical fact situation and then examining critically how the law applies to that situation, drawing on specially compiled subject materials and other resources. However, this form of problem solving is generally limited to a consideration of specific identifiable legal issues relevant to the particular topic of the subject being taught. It does not range more widely to other legal and non-legal components of the client's problem and the general context in which the problem has arisen. Unfortunately, this tends to set the parameters in which lawyers deal with clients' problems. Lawyers are liable to concentrate on one or more identifiable legal issues without taking a more holistic approach and exploring the broader context in which 
the problem has arisen. Since these hypothetical fact situations are devised as vehicles for raising contentious issues of law, the result is that the ensuing discussion will usually focus on the law, and closer examination of the human context is rare. The client is thereby marginalised.

\section{Techniques for Avoiding or Solving Disputes}

The ownership and sale of knowledge and expertise which characterises the legal profession imposes an obligation to effect the most efficient resolution of the client's problem. When a client seeks the assistance of a lawyer, the client may not even know whether the problem is a "legal" problem. The client relies on the lawyer for advice. What skills enable the lawyer to provide this advice? Lawyers are trained to analyse factual situations, identify legal issues, research the relevant law and advise on its application. Traditionally, lawyers have been exposed to litigation as the primary means of dispute resolution. Generally, this incorporates reference to now fashionable forms of alternative dispute resolution (ADR). It should be recognised that in law schools ADR is usually taught by lawyers, giving ownership of the techniques and procedures used to lawyers, thereby ignoring a vast wealth of community and other professional experience in problem solving. While there may be some exposure in clinical programs or legal practice courses, we are not aware of any course offered in Australian law schools which incorporates an understanding or knowledge of community or welfare services, systems or resources - for example, psychological or financial counselling, migrant resource centres or community justice centres.

A legal practitioner providing the most effective service for the client needs to have access to the widest range of problem avoidance and problem resolution techniques.

One has to remember the function of law. It is a tool used to solve problems not simply a body of knowledge. The measure of a competent lawyer is not an estimate merely of what law he or she knows but rather how that knowledge can be used to give effect to the legitimate goals of clients. If one cannot do this the ability to recite volumes of legal principle will be of little help. ${ }^{34}$

The difficulty for lawyers is that they are trained by lawyers about law and legal problem solving. It is often forgotten that legal problem solving is but one methodology for solving a problem.

\section{The Shock of Practice}

Should we therefore wonder that after three to five years of study one of the major surprises for new lawyers moving from law school into legal practice is the change of focus from appellate decisions and esoteric questions of law, to clients and clients' problems. We suspect that many law students fail to appreciate that clients are the raison d'etre of legal practice. Once in practice, the new lawyer will spend very little time on legal research, and esoteric questions of law will be few and far between. Instead, he or she will be faced with the practical needs of clients, handling files, drafting documents, writing letters, telephoning, performing administrative work, all of which are far removed from the academic cloister. The new lawyer will discover that the practice of law often involves operating a business for which work management and risk management are important issues.

Lawyers must also be awake to the changing nature of legal practice. For example, the last 25 years have seen significant advances in telecommunications and information technology, specialisation in legal practice, the abandonment of costs scales, the de-monopolisation of legal services, competitive tendering for legal work, the use of specialist lay advocates ${ }^{35}$ and the increasing use of tribunals for administrative decision-making and review of administrative decisions.

\section{A New Focus - Context and Clients}

How should law schools address this problem of context? What responsibility do they have to move beyond purely academic education to the nitty gritty of everyday legal practice? ${ }^{36}$ Most lawyers would, we think, agree that law schools have a responsibility to educate their students as to how law operates in their community - as to its practical application. Phrases such as "law in society" and "law in context" are frequently used by legal educators. This is not, however, meant to suggest that the law schools' principal aim is to educate their students to become legal professionals. One can assume that all law schools now emphasise to their students that a law degree is not a ticket into the legal profession. At least half of all law 
graduates will need to find careers elsewhere. ${ }^{37}$ But one cannot study law in a vacuum. Law has to be located in its political, social and cultural context for it to have meaning. Part of that context should include the client and the skills needed in communicating with the client, ascertaining the relevant facts, identifying the client's goals and relevant issues of law, outlining options, both legal and non-legal (including forms of ADR), and assisting the client to choose his or her preferred course of action, understanding what the consequences of that course are and what is entailed in working towards a solution to the problem.

Students should understand that the client's focus on a problem may be very different from that of the lawyer. Commonly, the client will not distinguish between those facts that are material or relevant to the legal issues involved and those that are not. From the client's perspective, there may not be any apparent need to do so, given that the client's focus is on resolving the matter whether the law is involved or not. Thus, the lawyer must start by listening in order to understand the general nature of the matter and ascertain the client's goals. This may require the lawyer to assist the client in formulating hitherto unstated goals. So the lawyer should never concentrate solely on the fads related to the perceived legal issue. This is liable to lead the lawyer astray. Other facts may have greater significance for the client and the matter may be resolved much more satisfactorily for the client using non-legal means.

Focusing on the client in this way highlights the importance of raising students' awareness of communication skills and encouraging them to practise and develop those skills. But it should be emphasised that the need for these skills is not unique to the lawyer. These skills are fundamental to all those occupations or professions where a service is provided to a customer or client. ${ }^{38}$

\section{FROM THE TRADITIONAL TO THE LIBERAL — LAW SCHOOLS IN TRANSITION?}

\section{Intellectual versus Vocational}

The Australian tradition is that the academic part of the training of legal practitioners is done by the universities. ${ }^{39}$

This traditional statement of the role of law schools still raises questions about what constitutes the training of legal practitioners and, in particular, the academic portion of that training. Does "academic" necessarily mean theoretical? An important question is whether the role of a law school is to produce a graduate with legal skills, or to produce a legal practitioner. ${ }^{40}$ Some academics argue strongly that the role of the law school is to promote intellectual rigour in studying the discipline of law and that the law school has no role in vocational training.

I view my task as a legal academic as similar more to the member of a university department of religion, somewhat detached from the practices he/she is studying ... One need not be a devotee of a particular religion in order to find its practices or doctrines fascinating. ${ }^{41}$

There are four issues which arise from this quotation. First, the quotation emphasises the function of the academic rather than the needs of the student. In the last ten years or so, there has been increasing recognition that learning methodology should be student centred. ${ }^{42}$ The teaching role of the academic should only be determined once the teaching and learning objectives and methodology have been established.

Secondly, whilst we agree that critical analysis is a fundamental component of legal education, such analysis should, in our view, take place in the context of how the law operates, or should operate, in the community. To do otherwise would be to deny students valuable insights into the systems and applications of law.

Thirdly there is an implicit assumption in the quotation that the study of law is purely intellectual and substance driven. It either assumes or ignores the underlying skills needed to deal with the substance of law. However, even intellectual rigour requires the development and practise of certain skills. These are referred to later in this paper.

Fourthly the quotation fails to recognise the impact of the law school on the values and ethical systems constructed by each student in the course of his or her law studies. How we teach and what we teach impacts upon this process. ${ }^{43}$

All law students need to develop a range of skills to handle the information, attitudes and values to which they are exposed. ${ }^{44}$ Although law schools have always taught skills, they are usually neither 
adequately articulated nor adequately described. The problem for law schools is that the impression is often given that in teaching skills they are breaking new ground. This is not the case, the difference being that some law schools are now teaching skills as part of a more structured, considered and articulated program. ${ }^{45}$

\section{Shifting Sands or Quicksand?}

The primary difficulty faced by those concerned with determining, understanding or interpreting the role of law schools is that the concept of the legal profession is undergoing a fundamental change which will necessitate a re-evaluation of legal education. Neither the law schools, nor the professional bodies, nor the admission authorities have sufficiently addressed these changes. For example, as Nash points out:

The division of legal education into stages is arbitrary, unnecessary and confusing. It confuses our aims. It bores the student. It sanctifies a division within the legal profession which should be abolished. It makes it harder for the student to learn his theory to understand practice; it requires him to go from the equivalent of the economist's model with only one variable to the realities of a world where multiple variables are the norm. ${ }^{46}$

In New South Wales, the relationship between academic study, skills training, clinical placement programs and practical legal training is in a state of flux. The law schools, the admission authorities and the professional bodies have not yet resolved what each should expect from the others as their contributions to professional or legal training. A particular consideration in most states is the divided nature of the profession, whether formal or informal, which has had the effect of complicating communication and negotiation for change in professional and legal training. However, while Australian law schools have traditionally followed a British model of legal education which distinguished between theory and practice, we are increasingly moving towards a more integrated American model:

The lawyers of the United States find no need for a system of post-graduate practical training whether by apprenticeship or institutional training; but they feed into their law courses and into particular aspects of their law courses a practical component. ${ }^{47}$

\section{Professional Training?}

The role law schools play in professional training is constrained by what we mean by professional training. Unless that meaning is shared by all relevant parties, confusion will result. If, as Duncan Kennedy has suggested, one of the effects of legal education is to instil adherence to professional standards and common understandings of the parameters of acceptable conduct, ${ }^{48}$ then law schools undoubtedly have a role. The study of law, the issues it raises, and the context in which it is studied, institutionalises students and moulds a shared understanding of law. Given the fact that law students typically spend 5 years in a law school environment, they will inevitably also acquire a shared understanding of expectations of what it is to be a lawyer and of a lawyer's role both in the legal system and society as a whole. Don Anderson, a sociologist from the Australian National University, reported on a study which he had conducted on the development of professional cultures. According to Anderson, the law students with whom he met in their first week of University:

were suspicious, demanding guarantees of confidentiality of a strictness which would have made the Australia Card look like a public notice. Despite undertakings of a scrupulous confidentiality, they remained the most suspicious, refractory and generally uncooperative ... these first years were already behaving like professional lawyers, taking nothing on trust, suspecting every proposition. ${ }^{49}$

Law schools need to recognise that there are consequences of legal education beyond the substantive curriculum which are unspoken and unacknowledged. ${ }^{50}$ The interaction of students and contact with law school staff and visitors may generate perceptions of practice which they take with them on graduation. Law schools should be aware of their responsibilities to the community at large to monitor this institutionalising process and the perceptions of their students in order to avoid, for example, the arrogance and elitism which the above quotation suggests. We should note, however, that the students interviewed by Anderson may have adopted a profile derived from a popular perception of the role of lawyers rather than one derived from the law school. 


\section{A Broader Role?}

A broader conception of the role of law schools in legal education has been expressed by Jack Goldring. He states that the duty and function of a university "is to encourage students to think and learn independently":

A University law school can and should effect a number of things. It must, above all, develop the student's ability to think critically, to question accepted wisdom and to examine rationally and coolly a range of optional solutions to any problem. That is the quintessence of the University education. Secondly it must give the student the opportunity to develop a deep and thorough understanding of any area of knowledge, in this case the law as it applies in Australia... . Finally, University legal education should develop the student's awareness of the context in which the law operates. ${ }^{51}$

Adopting this view provides opportunities to re-examine the curriculum to incorporate broader objectives in the teaching and learning of law. The teaching of what is sometimes described as theoretical law, that is without context or practical application — in any event an impossibility — will not of itself promote life long learning, reflective practice and critical evaluation. In order to achieve these goals, legal education should be a continuum — from undergraduate degree through practical legal training and into the profession, including continuing legal education while in practice.

Every law school in developing its objectives, including graduate attributes, needs to consider the professional, social and university environment, as well as funding constraints. Universities see benefits in establishing a law school because having a law school brings prestige to the institution for a program that in the past, at least, has been relatively low cost to teach. And since law students who are enrolling straight from school are usually required to enrol in a 5 year combined degree program, this has the effect of enrolling high calibre students in those other degrees with ensuing benefits in terms of quality of output. Consequently, over the last 5 years, the number of law schools and law students has increased exponentially, ${ }^{52}$ there being no national or State control over the number of law students.

However, while the number of law schools has increased, the number of students wishing to study law has remained relatively constant. Thus, there are students studying law now who, 5 years ago, would not have achieved entrance to a law school. This has resulted in increasing competition amongst law schools to attract the best students. Some law schools are therefore focusing on the attributes of their graduates, ${ }^{53}$ choosing either to produce a graduate for a specialist market ${ }^{54}$ or to produce a graduate who is an "all rounder”. If the law school makes an appropriate choice, it may become more competitive, with possible effects on staffing, research funding, the attraction of post-graduate students and prestige.

Another related issue which law schools must face is whether the curriculum should address the employment prospects of their graduates. For example, should the curriculum differ according to whether students intend to be legal practitioners and according to the type of legal practice intended. At least half of all law graduates will need to find careers outside the legal profession, and governments, corporations, banks, accountants, and financial institutions are all actively recruiting law graduates. ${ }^{55}$ However, even those students who do not have any immediate intention to practise will in many cases want to complete their professional training and be admitted so that they can keep the option of legal practice open. Many law schools are re-examining their identity as they head towards the millennium. As part of that process, they must take into account the changing nature of the legal profession, the wide-ranging employment opportunities for lawyers who do not choose traditional legal practice, and the needs of students with a diversity of personal and professional interests. A significant issue in this discussion is identifying the purpose for incorporating skills training into the law school curriculum. Client dissatisfaction with the legal profession, part of the responsibility for which must lie with the law schools, indicates that greater emphasis must be given to a client-centred approach to legal education. Skills are already taught in law schools. We should recognise that fact, build on it, articulate those skills and produce a better integrated legal education.

\section{SKILLS TEACHING}

A client-centred approach to legal education necessarily focuses on skills involved in providing a professional service for the client and in maintaining the lawyer/client relationship. In this part, we examine those skills currently taught in the law school curriculum, and consider whether those skills are client 
related. We then ask what skills might be included in the curriculum and with what effect. But before doing so, it may be helpful to consider two definitional questions. First, what do we mean by a "client"? Is the "client" necessarily the client of a legal practitioner, the consumer of legal services, or is the term to be used more widely to include any user of law. ${ }^{56}$ We prefer the latter meaning. Secondly, what do we mean by "skills", and which skills can we identify as appropriate to legal education? We consider this in more detail below.

\section{Definition of Skills ${ }^{57}$}

Although, in legal education, an agreed definition of "skills" has proved elusive, a number of writers have discussed the meaning of the term and there appears to be some general consensus. An expertise or practised ability - thus a level of competence — in doing something seems to be the core of the notion. ${ }^{58}$ Karl Mackie has identified a number of features which characterise "skilled behaviour": that it is directed towards achieving a particular result, that it is learned from practice, and that it involves coordinated activity which, with practise, will usually become intuitive. Such skilled behaviour can be further divided into microskills — comprising a sequence of choices, actions and reactions, that are responsive to the environment. ${ }^{59}$

Neil Gold divides skills into two main categories: skills which enable access to legal knowledge, and skills which involve the application or use of legal knowledge. ${ }^{60}$ However, whilst useful as a pointer to the object of skills, a number of the skills identified straddle both categories, and we have therefore decided to adopt a more traditional listing.

The headings in the following classification are not intended to be exclusive. Because of the nature of skills — each nominated skill comprising a number of microskills — there is considerable overlap between one heading and another. For example, the gathering of facts is an important part of interviewing as well as rating a separate heading; and ethical considerations are implicit in a number of skills including problem solving, interviewing and litigation.

\section{Classification of Skills}

\section{Legal Analysis and Reasoning}

Including:

- analysis of cases, especially interpretation

- analysis of legislation, especially interpretation

- identification and formulation of legal issues

- synthesis and critical evaluation of legal argument

- identification, elaboration and evaluation of relevant law and legal theory

- application of legal rules and principles

\section{Legal Research}

Identification and research of legal issues, including:

- knowledge of the nature of legal rules and institutions

- knowledge and ability to use legal research tools

- design and implementation of research projects

\section{Problem Solving}

Including:

- identification and diagnosis of a problem

- generating alternative and creative strategies and solutions

- principled and ethical decision-making

- devising a plan to implement the decision

- evaluation of action and remaining open to change

- ability to work independently or with others 
- teamwork skills, including understanding group dynamics, allocation and supervision of tasks, effective team building and dispute resolution

\section{Communication Skills}

Including:

- the ability to communicate effectively either orally or in writing

- evaluating a situation and audience and identifying the most appropriate form and level of communication

- assessing the perspective of the recipient of a communication

\section{Factual Investigation}

Including:

- determining the need for gathering information

- planning the investigation

- implementing the strategy

- recording and classifying the information appropriately

- evaluating the information

\section{Interviewing and Advising}

Including:

- pre-interview preparation

- establishing a professional relationship with the client

- recognition and appropriate handling of ethical issues

- gathering of information

- listening skills (both passive and active)

- questioning skills

- analysis of facts and law

- generation of legal and non-legal options

- advising the client

- ascertaining and implementing a client's decision

Negotiation, Mediation and Other Forms of Alternative Dispute Resolution

In accordance with the client's instructions, preparation for and conduct of:

- negotiations

- mediation

- other forms of alternative dispute resolution (eg mini-trial)

\section{Litigation}

Including:

- knowledge of functions, procedures and outcomes of different courts and tribunals

- understanding of ethical issues

- advocacy in a variety of courts and tribunals

\section{Organisation and Management of Legal Work}

Including:

- formulating goals for effective practice management

- developing and implementing effective and efficient systems and procedures for appropriate client care

- developing and implementing procedures for regular auditing of legal work

- promoting a productive working environment

\section{What Skills do Law Schools Teach?}

Because of recent developments in legal education, skills teaching tends to be associated with practical 
skills involved in legal practice. As noted above, it is of course true that law schools have always been involved in skills teaching. Legal analysis, legal reasoning and legal research are fundamental skills traditionally taught in all common law law schools. Some aspects of problem solving skills - for example, identification and diagnosis of a problem and generating solutions - have also been a traditional part of the curriculum. But these skills have tended to be assumed and often not articulated. Most importantly, none of these traditionally taught skills except, to a limited extent, problem solving, are client-centred. Indeed, most of the other skills which are client-centred and which give context and realism to legal education, have traditionally been neglected.

We should also note that in teaching the traditional skills, such as research skills, law schools commonly do not teach (or allow for self-teaching) in a logical, progressive and clearly articulated sequence. Typically, research skills are taught in a single discrete subject, usually in the first year of the law degree program. Often, no attempt is made to reinforce and develop those skills as the student proceeds through the degree. Many academics make assumptions about the level of their students' research skills, even though these may vary widely among students in the same class who may also be in different years of their degree program.

\section{What Skills Should Law Schools Teach?}

In chapter two of the "Summary" volume of the Pearce Report on Australian Law schools, ${ }^{61}$ it was suggested that:

The Committee thinks it desirable, if the resources, staff and time in undergraduate programs can be found, that law schools make a greater contribution to the development of some skills. Schools may well have to select between the skills training that they offer having regard to their capacity and resources but it seems to us that law schools cannot put to one side the views of their graduates and the extensive US literature on this issue. ${ }^{62}$

Some law schools have acted on this suggestion. For example, the following statement appeared in the original University of Wollongong law degree curriculum proposal:

Skills are an important part of a legal education: they assist understanding of what is happening within the legal system, and their application plays a vital part in the operation of the legal system. Study of law-related skills can be justified on intellectual as well as professional grounds. An additional argument in favour of the teaching of legal skills as part of a law degree course is that it reinforces the central theme that the law is concerned about people.

As we have said, law schools have always taught skills. The difficult questions which must be answered when attempting to develop an articulated program of skills teaching are first, what skills will be taught, secondly, how will those skills be taught, and thirdly where will those skills be taught. Later in this paper we will outline a research program which addresses these questions. We list below some of the benefits and hurdles to including client-centred skills in the curriculum. ${ }^{63}$

\section{The Benefits of Including Client-centred Skills in the Curriculum}

- Client-centred skills give context to students' learning. ${ }^{64}$ The law is more meaningful and interesting if students can see how law is applied and works in practice. Our experience is that there is strong student demand for this perspective. Consequently, students are likely to be more highly motivated and enthusiastic and, as a result, produce work of a higher standard.

- Client-centred skills refocus students' attention away from the narrow appellate decision/case analysis focus which has been encouraged by traditional legal education to a broader, more realistic perspective.

- The inclusion in the curriculum of client-centred skills enables students to apply their legal knowledge so that they learn how to make the law work for the client. The concept of legal education is thereby broadened, doing away with the artificial distinction between legal theory and legal practice.

- Requiring students to think of problems from the perspective of the client encourages them to think laterally and creatively, and to recognise that most problems are multidimensional and not neatly compartmentalised into divisions of substantive law.

- Client-centred skills promote an awareness that for lawyers the facts of a case are often equally as important as the law, and that the investigation, collection and synthesis of facts is a significant aspect of the lawyer's task. Many Australian law students enter law school at the age of 18 or 19, straight from school. They come to law school for a variety of reasons: ${ }^{65}$ 
— a few because they have a burning desire to study law or to practise as lawyer;

- some because they have been impressed by the glamour of law as seen in television and film portrayals such as The Firm, A Few Good Men, L.A. Law or Janus; ${ }^{66}$

- others because they do not want to "waste" high Higher School Certificate or tertiary entrance marks which are sufficient to secure a place in an undergraduate program in medicine, law or dentistry; or

— because law is regarded as a reasonably secure and well-paid profession.

Studying client-centred skills provides a window on to a real world or at least realistic situations where facts are usually more important than law. Law schools have been criticised for excessive "ruleorientation" ${ }^{67}$ Students are too little confronted by difficult fact situations where sorting out the facts may be more important and more difficult than sorting out the applicable law. An appreciation of the significance of facts and the context in which law is applied may well change a student's thinking about law.

- Client-centred skills promote an awareness of the professional and ethical obligations of lawyers. ${ }^{68}$ For example, simulated interviews are a good way of raising awareness of moral and ethical issues which can arise in the course of the lawyer/client relationship, and of appropriate responses to such issues.

- Because an important component of most skills subjects involves learning by doing, client-centred skills tend to promote student-centred learning in which students are active participants in their own learning. Students learn by doing, from constructive feedback, self-evaluation and reflection. ${ }^{69}$ Thus skills also help students to learn more about themselves and their strengths and weaknesses and to develop greater confidence in their ability to handle legal problems.

- Inclusion of client-centred skills in the law school curriculum, recognises the importance of skills to legal practice and the first part of the legal education continuum - the law degree - from which students progress to the practical legal training component of their education and on to continuing legal education while in practice. The inclusion of skills in the law degree is not intended to displace any part of the practical legal training component. It is more likely to be an awareness raising exercise, in terms of the significance of skills, with only limited practice of those skills. This groundwork can then be reinforced and developed in the practical legal training component.

- Many client-centred skills are generic. For example, almost everyone needs communication skills - to be aware of and capable of using interpersonal skills. ${ }^{70}$ To be able to listen, to ask questions, evaluate evidence, recognise issues, diagnose problems and identify solutions, are basic to human relations. The ability to communicate effectively is essential for all forms of employment and to establishing and maintaining personal relationships. The practise of good communication skills will both minimise client complaints and improve the standing of the legal profession. ${ }^{71}$

- Client-centred skills tend to promote preventive law ${ }^{72}$ through the use of law as a means of avoiding legal problems or, at least, of resolving legal problems without being focused on litigation as the principal means of achieving a solution. In particular, because the majority of legal work takes place in the lawyer's office, we should pay more attention to what happens there, for example, in the course of a lawyer/client interview. ${ }^{73}$ In the past, law schools have tended to emphasise litigation as the principal means for resolving disputes. The emphasis in an interview, for example, should not only be on possible legal options for resolving a problem: the lawyer should canvass with the client the range of appropriate legal and non-legal alternatives, giving consideration to the economic, social and psychological consequences of particular courses of action. Such client counselling should also expose students to the importance of strategy, tactics and planning in pursuing a particular outcome. ${ }^{74}$

- Skills based subjects provide welcome relief from heavier, academic subjects. They also provide a clientcentred perspective for the study of substantive law.

- Where students' interpersonal skills are more developed as a result of studying skills subjects, this will improve the learning environment. Students' capacity to listen and to ask questions may be enhanced and, as a result, they should be capable of more effective participation in class. Where the emphasis in law school is on student-centred learning, the integration of client-centred skills into appropriate substantive law subjects such as family law, criminal law, welfare and housing law or torts provides variety and challenges for classroom activity and assessment. 


\section{Hurdles $^{75}$ to Including Client-centred Skills in the Curriculum}

- Resistance to skills teaching. It is sometimes argued that universities are for "academic" study — that the role of universities is to develop students' intellectual skills. ${ }^{76}$ Therefore, skills training should be confined to the vocational, practical legal training programs and not included in university degree programs. Some critics go further and claim that skills are "soft, indescribable, unteachable and unlearnable. ${ }^{77}$ The argument that skills lack an intellectual basis was addressed by Chris Roper in a 1994 paper. ${ }^{78}$ Quoting the Pearce Report's statement of the essential goals for legal education as including "intellectual skills of reasoning, analysis, critical thought and enquiry and skills of research and of bringing to bear theory, policy and information on the solution of problems", ${ }^{79}$ Roper rightly comments that "there is a false assumption that these intellectual skills are somehow not practical". Intellectual skills are not necessarily about coverage of substantive law or assimilation of large amounts of legal information. They include practical skills involving, for example, analysis, abstract reasoning, reflection, problem-solving, research and writing.

Skills subjects have been criticised as lacking a sufficient theoretical basis. ${ }^{80}$ While, in the past, there were few texts on client-centred skills, this has been changing rapidly in recent years and there is plenty of scope for providing skills teaching which can be reinforced by class discussion.

- Resource Implications. It is often said that teaching skills subjects is teacher intensive and expensive. Videotaping, individual critiquing, and, for example, the provision of law office settings for interviews can be costly and time consuming. Certainly, skills teaching requires small group work — but this can be undertaken within a larger seminar group if the seminar time is properly planned with a variety of different activities. And skills training is reliant on both staff commitment and available expertise. But our experience, for example in running a client interviewing program, is that it need not be overly expensive although it obviously depends on how the program is structured and taught. For example, members of the local legal profession may be prepared to talk with students about their experiences and assist in evaluating students' performance. It is, however, important that simulation exercises be realistic and carefully designed. If skills exercises are superficial, students will be bored. ${ }^{81}$

- An Overcrowded Curriculum. To satisfy the Uniform Admission Rules, a law degree must include 11 prescribed areas of knowledge, commonly referred to as the "Priestley Eleven". ${ }^{82}$ Given the need for a range of other electives, it is argued that the inclusion of skills training in the law school curriculum diminishes the time available for other subjects. The curriculum is crowded enough as it is. Should we be including additional subjects which can be taught in a professional training program? Such an argument suggests that skills subjects require the same sort of time commitment as stand alone substantive subjects. This is not, we would suggest, correct. Our experience is that much can be achieved with stand alone skills subjects with a time commitment of about one quarter of that required for substantive subjects. With a basic awareness of skills, students can then go on to practise and develop their skills in substantive subjects where a skills component is integrated into appropriate learning objectives and subject curricula. For example, the interview can be used as a scenario for problem-based or problem method learning in teaching ethics, criminal law or family law.

\section{CHANGING THE LAW SCHOOL CURRICULUM}

\section{A Client-Centred Approach}

Wade has drawn attention to the lack of focus in the standard law school curriculum: "The law school curriculum is standardly a scissors and paste jumble of unrelated stop-start topics administered by Lone Rangers." ${ }^{\circ 3}$ This is often the consequence of small changes over a number of years without reflection on the curriculum as a whole. He identifies correctly how the curriculum commonly develops. First, there are the external pressures from the legal profession and the admission authorities (referred to above) to include a range of core subjects in the curriculum in order to obtain approval for professional accreditation purposes. Then there are teachers who, for good reason, wish to teach in areas they are currently researching. They may therefore propose new elective subjects which draw on their research. Over time, there is a danger that the goals ${ }^{84}$ of the degree program may be forgotten. Undoubtedly, we should stand back from time to time and rethink the goals of our programs. Most legal academics would recognise the teaching paradigm in 
problem solving which encourages a focus on identifying legal issues and applying the relevant law rather than ascertaining and meeting the client's needs and goals. The difficulty that this creates over time is that the student sees legal problem solving not from the point of view of providing the resolution of a dispute for a particular client, but from the point of view of an "objective" application of law. In law schools, partly because there is no articulated and progressive hierarchy of skills in problem solving (or more correctly dispute resolution), it is difficult to link learning objectives, teaching methodology and assessment procedures in a way that promotes anything other than the learning of a discrete body of knowledge in isolation from the client's needs, non-legal problem solving resources and even other discrete bodies of knowledge. In other words, the structure of a law school and the needs of a modular curriculum work against the creation of a well integrated teaching and learning process which places law in its context and not as its raison d'etre.

The arguments for problem-based learning are persuasive. Thus, we should look beyond the law school curriculum to the design of individual subjects. Rather than compartmentalising our study into neat, discrete individual subjects, we should consider, where appropriate, focusing on broader law-related themes such as community welfare, the workplace, or obligations in which the relevant law may cross a number of substantive law boundaries in the same way that problems have a habit of doing in the real world. ${ }^{85}$

It has also been argued that law schools have ignored the role of lawyers in dispute avoidance. Nash says:

Most lawyers are not litigators; still less are they concerned to argue in the High Court the appropriateness or otherwise of following a particular line of authority (in relation to, for example, excessive force used in selfdefence). They are dispute avoiders; they are facilitators. Yet the student is given little or no insight into the role of the lawyer as a dispute avoider - as one who helps the client to arrange his affairs so that litigation does not ensue. ${ }^{86}$

The changing nature of the legal profession and the diverse non-traditional employment opportunities now available to law graduates also require a re-examination of the objectives and outcomes of legal education:

In many ways the profession of law is a new profession within an old one. The number of law schools has doubled in the past two years, putting great pressure on traditional academic models and creating the potential for enormous change in the way legal education is delivered, and to whom it is delivered. No longer is it reserved for the future barrister and solicitor, it is now open to the para-legal practitioner, the environmental scientist, the public administrator, the journalist and the school teacher. ${ }^{87}$

We therefore propose that the curriculum should be reexamined with a view to adopting a more clientcentred approach to legal education. As already indicated, a client-centred approach inevitably means greater emphasis on teaching the skills involved in providing a professional service to the client and in maintaining the lawyer/client relationship. But how do we go about incorporating appropriate skills in our curriculum?

\section{Integrating Skills into the Wollongong Curriculum}

The Faculty of Law at Wollongong has been involved in the development and teaching of skills since its establishment in 1990. Initially, the focus lay in establishing stand alone skills subjects within the law degree program: a core of six compulsory skills subjects were included: Legal Research \& Writing, Communication Skills (including client interviewing), Advocacy \& Negotiation (including ADR), Drafting \& Conveyancing Practice, Litigation Practice, and Computer Skills. The remainder of the law degree program comprises a number of compulsory and elective substantive law subjects. One of the consequences of "separating out" these skills subjects has been a lack of development and articulation of those skills in the substantive law subjects. With the exception of those subjects requiring the completion of pre-requisite subjects, the substantive law subjects of the Law Faculty are not generally progressive in skills required of students.

We need to build on the foundation of stand alone skills subjects by integrating those skills into the mainstream curriculum and encouraging their further development by articulating and developing skills within the learning objectives, teaching methodology and assessment regimes of appropriate substantive law subjects. ${ }^{88}$ For example, the learning objectives of a subject should particularise the skills and level of competence sought, which should be addressed in the teaching methodology and reflected in the assessment 
tasks. Some non-traditional skills are already incorporated, to a greater or lesser degree, in a number of substantive subjects. But this has occurred because of interest from particular staff members and not as a result of any general approach to teaching. We have therefore initiated a research project ${ }^{89}$ to consider how skills can be better integrated into the curriculum. First, a "skills audit" of both substantive and skills based subjects in the LLB curriculum has been conducted. The audit examined subject objectives, teaching methodology and assessment tasks. As part of the audit, a researcher interviewed subject coordinators. The information derived from the audit has been examined with reference to the classification of skills outlined above, and an interim discussion paper is being prepared for distribution to the Faculty for comment. The paper will also be distributed for discussion at an open forum of undergraduate students in order to elicit their comments and concerns.

Secondly the project will investigate how skills may be integrated into the teaching of substantive subjects and identify those subjects which are appropriate to the integration of particular skills. The researcher will conduct follow up interviews with individual staff members with a view to identifying options for the development of appropriate skills for integration into their subjects. Thirdly a pilot will be conducted involving at least one subject to evaluate how well ideas generated in the project translate into practice. Finally, a report will be prepared on how the integration of skills may be achieved, and a University seminar will be conducted on the outcomes of the project.

\section{CONCLUSION: A NEW FOCUS?}

By adopting a client-centred approach to legal education much else falls into place. It will give context and relevance to students' learning, greater emphasis to ethical rules and professional values by its focus on the relationship between lawyer and client, a better understanding of the practice of law, and prepare students for the change of focus to which they must adjust when moving from law school to "work".

Obviously, some skills subjects such as communication skills, interviewing, counselling, negotiating, and mediation would be meaningless without reference to the client. But we have argued that the introduction of the client into the law school curriculum also has substantial benefits for the teaching of substantive law subjects.

Re-introducing the client into the curriculum need not be expensive. Certainly, some rethinking is required in terms of the approach to legal education, our goals and the consequent need to revise our programs and the curriculum of individual subjects. This should be reflected in staff development programs. Learning must be a reflective, organised and systematic learning experience, and staff must be encouraged to stand back and take a broader view of what they are doing and what they want to achieve.

Maybe we should take heed, look to our credibility, and show that what we do is relevant to what happens in the real world. There is also the benefit to students who will have a context for their learning and who, thereby, will probably be more motivated to learn and find doing so a more enjoyable experience. If a spark of enthusiasm can be lit, then the profession may be able to promote more successfully the continuing legal education — more generally the process of lifelong learning — which should characterise an enlightened profession.

* Associate Professor, Faculty of Law, University of Wollongong

** Senior Lecturer, Faculty of Law, University of Wollongong (C)1997. (1996) 7 Legal Educ Rev 193.

1 For a comparison with the position in the United States, see C Laredo- Fromson, Meeting the Challenges of Client Dissatisfaction (1995) 13 J Prof Legal Educ 81. For England \& Wales, see eg Great Britain, Fourth Annual Report of the Legal Services Ombudsman 1994 (London: HMSO, 1995) HC 459, at 3, para 2.8, \& at 4, para 2.15.

2 T Matruglio, Plaintiffs and the Process of Litigation (Sydney: Civil Justice Research Centre, 1994).

3 Id at 16-17.

4 CN Candlin et al, The Language of Lawyer-Client Conferencing (Sydney: Centre for Language in Social Life (Department of Linguistics, Macquarie University), 1994)

5 Id at 12.

6 Id at 46.

7 R North, \& P North, Managing Client Expectations and Professional Risk (Sydney: Streeton Consulting, 1994) [referred to as The North Report].

8 Id at ix.

$9 \quad$ Id at 1. 
10 Id at 2.

11 Id at 11.

12 Id at 12.

13 Id.

14 Id.

15 Id at 21.

16 Id at 24.

17 Id at 27.

18 Id.

19 Id at 29.

20 Id at 36.

21 Id at 38.

22 P Wolfe, Areas of Risk in Legal Practice. The pattern of complaints against lawyers (1994) 6 L Soc'y 149.

23 Id at 51.

24 Under the terms of the indemnity policy, solicitors must give LawCover written notice of circumstances that could give rise to a claim being made against the solicitor even though no claim may eventuate.

25 Since 1 July 1995, Tasmania and Western Australia have withdrawn from the LawCover scheme and have arranged their own professional indemnity arrangements.

26 L Nicholls, Claims in the 1994 Policy Year (1995) Stoploss (newsletter of LawCover) 3, at 4.

27 The Office of the Legal Services Ombudsman, Annual Report 1994-95 (Sydney: Office of the Legal Services Ombudsman, 1995) 21. The office received 2801 written complaints in 1994-95 (at 4).

28 The North Report, supra note 7.

29 M Conners, Flying Start for the Risk Education Management Program (1995) Stoploss 3, at 1.

30 M Conners, The Year of Risk Management (1995) Stoploss 3, at 1.

31 Laredo, supra note l, at 90

32 M Le Brun, \& R Johnstone, The Quiet (R)evolution: Improving Student Learning in Law (Sydney: Law Book Company, 1994) 283.

33 Id at 93. The problem method of learning should be contrasted with problem-based learning which involves students learning in the process of solving a problem.

34 DA Yap, Lawyer Competence in a Changing World, uncited quotation in N Gold, Professional Education for Tomorrow's Lawyers (1991) 9 J Prof L Educ 47.

35 The Victorian Attorney-General, MS Jan Wade, has proposed that non-lawyers with experience in areas such as unfair dismissal, accounting and engineering be allowed to represent people in courts and tribunals, especially in administrative tribunals where the tribunal operates inquisitorially and is not bound by the rules of evidence. See the Report of the Working Party on the Victorian Legal Profession released on 6 September 1995: N Brady, \& P Conroy, New legal elite in shakeup plan The Age 7 September 1995 , at 5 .

36 R Johnstone, Rethinking the Teaching of Law (1992) 3 Legal Educ Rev 17, at 22ff.

37 According to the Newsletter of the Centre for Legal Education Vol 4 No 3 September 1995 at 3, in July 1995 there were 22,512 undergraduate law students studying law in 26 law schools in Australia and 30,377 lawyers practising as barristers or solicitors. It should be borne in mind that many of these students are undertaking 5 year combined degree courses.

A recent report, C Roper, Career Intentions of Australian Law Students (Canberra: AGE, 1995), states that in 1994 there were 5,150 first year law students and 3,096 final year law students in 24 law schools (at xiv). This report, the result of a survey of law students, reveals that only $48 \%$ of the 1629 final year students responding to the survey wanted to work in the private legal profession. (75\% of final year respondents planned to be admitted within 2 years or probably within 5 years. But of these, only $62 \%$ planned to work in the private profession.) Of those who planned to work in the private profession, $41 \%$ "maintained that their second [career] preference was just about as satisfactory as their first preference". The report concludes that "[i]n effect, only $28 \%$ of final year respondents are intent on working in the private legal profession” (at 89-91).

38 R Hyams, The Teaching of Skills: Rebuilding — Not Just Tinkering at the Edges (1995) 13 J Prof Legal Educ 63 , at 64.

39 Justice RE McGarvie, The Function of a Degree: Core Subjects (1991) 9 Prof Legal Educ 11, at 12

40 F Martin, The Integration of Legal Skills into the Curriculum of the Undergraduate Law Degree: the Queensland University of Technology Perspective (1995) 13 J Prof Legal Educ 45, at 46; G Gasten, National Competency Standards: Are They the Answer for Legal Education? (1995) 13 J Prof Legal Educ 1, at 4: Hyams, supra note 38, at 74.

41 Judge HT Edwards, The Growing Disjunction between Legal Education and the Legal Profession (1992) 91 Mich L Rev 34, at 36, quoting from a letter to the author, Judge Edwards.

42 Le Brun, \& Johnstone, supra note 32.

43 I Duncanson, Legal Education, Social Justice and the Study of Legality (1990) 10 U Tasmania L Rev 16, at 25.

44 See for example the skills classification set out later in this paper.

45 For example, law schools at Wollongong, Bond, Flinders and Griffith Universities.

46 G Nash, Should Law Schools Produce Lawyers? (1991) 9 J Prof Legal Educ 27, at 30

47 Id at 32

48 D Kennedy, Legal Education as Training for Hierarchy, in D Kairys ed, The Politics of Law: A Progressive Critique (New York: Pantheon, 1982) 38.

49 Don Anderson, quoted by A Susskind, How Education Dehumanises Professions Sydney Morning Herald 13 December 1990 , at 13.

50 Kennedy, supra note 48.

51 J Goldring, Networking: Law Schools and Practical Legal Training Institutions (1993) 11 J Prof Legal Educ 79, at 82.

52 Hyams, supra note 38. 
53 Bond University and the University of Wollongong have incorporated specific skills subjects or training into their undergraduate curriculum.

54 The University of Canberra has adopted a strongly corporate law/ commercial law orientation and Southern Cross University has developed a program for intending rural practitioners.

55 Goldring, supra note 51, at 80.

56 By "user of law" we mean any person who comes into contact with the legal system, for example, whether as witnesses, jurors, or those who use the law for a variety of purposes.

57 This relies heavily on the list of fundamental skills and values identified in the Report of the Task Force and the Profession: Narrowing the Gap (MacCrate Report) Legal Education and Professional Development - An Educational Continuum (Chicago: American Bar Association, 1992), especially at 138ff, and Le Brun, \& Johnstone, supra note 32, at 171-73. See also N Gold, Are Skills Really Thrills? (1993) $11 \mathrm{~J}$ Prof Legal Educ 1, and Martin, supra note 40, at 49. For an indication of the view of the practising profession, see J de Groot, Acquiring Basic Legal Skills and Knowledge: What and Where (1994) 12 J Prof Legal Educ 1 .

58 K Mack, Bringing Clinical Learning into a Conventional Classroom (1993) 4 Legal Educ Rev 89.

59 K Mackie, Lawyers' Skills: Educational Skills, in K Mackie et al, Learning Lawyers' Skills (London: Butterworths, 1989 ) 9.

60 “[A] realist skills-oriented curriculum seeks to teach students the way law works and to teach new lawyers to make law work for their clients": Gold, supra note 57, at 4-5.

61 Commonwealth Tertiary Education Commission, Australian Law Schools: A Discipline Assessment for the Commonwealth Tertiary Education Commission (Pearce Report) (Canberra: AGPS, 1987). See also the comments on skills training in C McInnis, \& S Marginson, Australian Law Schools after the 1987 Pearce Report (Canberra: AGPS, 1994), especially at 168-170.

62 Pearce Report, supra note 61, at 52.

63 Generally, see eg J Wade, Legal Skills Training: Some Thoughts on Terminology and Ongoing Challenges (1994) 5 Legal Educ Rev 173; Mack, supra note 58; Gold, supra note 57; A Leaver, Contextualising Law: An Attempt to Operationalise Theory by Teaching Interviewing in the Law School (1994) 5 Legal Educ Rev 195.

64 Le Brun, \& Johnstone, supra note 32, at 170.

65 A recent report for the Centre for Legal Education, C Roper, Career Intentions of Australian Law Students (Canberra: AGPS, 1995) xiv and Table 4.2, states that the most popular reason for studying law was an interest in the subject matter of the law; secondly, that doing law as part of a double degree increases career options; thirdly, that being a general degree, law provides a good basic training for a number of career options; and fourthly, that there are good prospects for getting a job.

66 Roper (id at 31), notes there is no quantifiable evidence of this; there is, however, a range of anecdotal evidence.

67 Id at 102.

68 Mack, supra note 58, at 90; K Lauchland, \& M Le Brun, Legal Interviewing - Theory, Tactics and Techniques (Sydney: Butterworths, 1996) ch 12.

69 Mack, supra note 58, at 91ff. See also Centre for Research in Professional Education, How Australian is Professional Education in Australia? Discussion Paper (Canberra: Centre for Research in Professional Education, 1992) 7: "What students require is the ability to reflect on practice. They must acquire the habit of criticising their learning by applying it to their knowledge of and experience of society."

70 On interpersonal skills, see eg R Bolton, People Skills (Sydney: Simon \& Schuster, 1987).

71 Hence LawCover's “Risk Management Education” program in NSW and the ACT.

72 F Mosten, The Unbundling of Legal Services: Increasing Legal Access, in R Smith ed, Shaping the Future (London: Legal Action Group, 1995) 47 at 56.

73 On client-centred interviewing, see eg R Bastress, \& J Harbaugh, Interviewing, Counseling and Negotiating (Boston: Little Brown, 1990); D Binder, P Bergman, \& S Price, Lawyers As Counselors (Minnesota: West Publishing, 1991); J Chapman, Interviewing and Counselling (London: Cavendish Publishing, 1993); Lauchland, \& Le Brun, supra note 68; T Shaffer, \& J Elkins, Legal Interviewing and Counseling 2nd ed (Minnesota: West Publishing, 1987); A Sherr, Client Interviewing for Lawyers (London: Sweet and Maxwell, 1986); H Twist, Effective Interviewing (London: Blackstone Press, 1992); N Gold et al, Learning Lawyers' Skills (London: Butterworths, 1989).

74 Mack, supra note 58, at 100.

75 John Wade's description in Wade, supra note 63, at 183.

76 See above.

77 Gold, supra note 73, at 4.

78 C Roper, Issues in Skills Training in Australia, paper presented at the Professional Legal Skills Conference, Bond University, 10 February 1994.

79 Pearce Report, supra note 61, at 7.

80 Mack, supra note 58, at 89.

81 Wade, supra note 63, at 185.

82 After Justice Priestley who chairs the Consultative Committee of State and Territorial Law Admitting Authorities which drafted the Rules. The 11 prescribed areas of knowledge are: Criminal Law and Procedure, Torts, Contracts, Property both Real (including Torrens system land) and Personal, Equity, Administrative Law, Federal and State Constitutional Law, Civil Procedure, Evidence, Company Law, Professional Conduct (including basic trust accounting).

83 Wade, supra note 63, at 185-186.

84 Id at $175 \mathrm{ff}$.

85 Le Brun, \& Johnstone, supra note 32, at 382.

86 Nash, supra note 46, at 31.

87 Centre for Research in Professional Education Discussion Paper, How Australian is Professional Education in Australia? (Canberra: Centre for Research in Professional Education, 1992) 2.

88 Martin, supra note 40, at 53.

89 The authors acknowledge the assistance of the Law Foundation of NSW Legal Scholarship Support Fund and the University of Wollongong Teaching Development Grant Scheme, both of which have provided funds for this project. 
